\title{
Analisis Dampak Lalu Lintas Akibat Pembangunan Apartemen Puncak Dharmahusada Surabaya
}

\author{
Abdul Rahman ${ }^{1, *}$, Machsus Machsus ${ }^{1}$, Amalia Firdaus Mawardi ${ }^{1}$, Rachmad Basuki ${ }^{1}$ \\ Departemen Infrastruktur Sipil, Fakultas Vokasi, Institut Teknologi Sepuluh Nopember, Surabaya \\ Koresponden*, Email: abdulrahmani8714001@gmail.com
}

\section{Info Artikel}

Diajukan 19 Juli 2018

Diperbaiki 04 Oktober 2018

Disetujui 15 Oktober 2018

Keywords: Traffic impact, MKJI 1997, delay, LOS

\section{Abstract}

This paper will analyze the traffic problems that occur due to changes in land use, both changes in categories and intensity. The aim is to analyze the traffic impact due to the construction of the Puncak Darmahusada Apartment in Surabaya. This research method begins with the collection of primary data and secondary data. Primary data includes field surveys, road geometric, traffic flow volume, and traffic light settings. The secondary data includes administrative boundaries, road networks, building characteristics, and movement models of similar buildings. Furthermore, an analysis of the performance of the road and intersection in accordance with MKJI 1997, and analysis of trip attraction and trip generation is carried out. The results obtained indicate that the existing condition of the signalized intersection $\mathrm{Jl}$. Dr. Ir. Soekarno - Jl. Mulyorejo with LOS F and delay of 510.74 det / pcu. At the signalized intersection Jl. Dr. Ir. Soekarno - Jl. Kalijudan in the existing condition shows LOS C with a delay of $20.18 \mathrm{sec} /$ pcu. Existing conditions of signalized intersection Jl. Dr. Ir. Sukarno - Jl. Kenjeran shows LOS F with a delay of 94.35 det / pcu. Recommendations for improving performance are changing the phase and green time at signalized intersections Jl. Dr. Ir. Soekarno - Jl. Mulyorejo and the signalized intersection Jl. Dr. Ir. Soekarno - Jl. Kenjeran.

\begin{abstract}
Abstrak
Pada makalah ini akan dibahas permasalahan lalu lintas yang terjadi akibat perubahan tataguna lahan, baik perubahan kategori maupun intensitasnya. Tujuannya adalah menganalisis dampak lalu lintas akibat pembangunan Apartemen Puncak Darmahusada Surabaya. Metode penelitian ini diawali dengan pengumpulan data primer dan data sekunder. Data primer meliputi survei lapangan, geometrik ruas jalan, volume arus lalu lintas, dan pengaturan lampu lalu lintas. Adapun data sekunder meliputi batas administratif, data jaringan jalan, data karakteristik bangunan gedung, dan model pergerakan dari bangunan sejenis. Setelah itu, dilakukan analisis kinerja ruas jalan dan persimpangan sesuai MKJI 1997, dan analisis bangkitan dan tarikan. Hasil yang diperoleh menunjukkan bahwa kondisi eksisting simpang bersinyal Jl. Dr. Ir. Soekarno - Jl. Mulyorejo dengan LOS F dan tundaan 510,74 det/smp. Pada simpang bersinyal Jl. Dr. Ir. Soekarno - Jl. Kalijudan pada kondisi eksisting menunjukkan LOS C dengan tundaan $20,18 \mathrm{det} / \mathrm{smp}$. Kondisi eksisting simpang bersinyal Jl. Dr. Ir. Soekarno - Jl. Kenjeran menunjukkan LOS F dengan tundaan 94,35 det/smp. Rekomendasi untuk perbaikan kinerja adalah merubah fase dan waktu hijau pada simpang bersinyal Jl. Dr. Ir. Soekarno - Jl. Mulyorejo dan simpang bersinyal Jl. Dr. Ir. Soekarno - Jl. Kenjeran.
\end{abstract}

pemukiman, dan infrastruktur yang hasilnya di tuangkan dalam bentuk dokumen hasil analisis dampak lalu lintas. Andalalin digunakan sebagai syarat untuk mendapakan Izin Mendirikan Bangunan (IMB), terutama bangunan yang dianggap menimbulkan dampak terhadap kondisi lalu lintas. Dalam Andalalin, dilakukan perhitungan besaran dampak yang timbulkan akibat pembangunan pusat kegiatan baru atau perubahan fungsi lahan terhadap kondisi lalu lintas suatu kota serta pembuatan strategi mitigasi untuk meminimalisasi dampak tersebut [1],[2].

.Kota Surabaya menjadi salah satu kota yang menerapkan kebijakan Andalalin sebagaimana dalam Peraturan Daerah
2009, Andalalin adalah serangkai kegiatan kajian mengenai dampak lalu lintas dari pembangunan pusat kegiatan, 
Kota Surabaya Nomor 12 Tahun 2006 tentang Analisis Dampak Lalu Lintas di Jalan dan Peraturan Walikota Surabaya Nomor 57 Tahun 2009 tentang Pelaksanaan Peraturan daerah Kota Surabaya Nomor 12 Tahun 2006 tentang Analisis Dampak Lalu Lintas di Jalan. Seiring dengan majunya teknologi dan semakin meningkatnya taraf hidup diperkotaan maka dibutuhkan fasilitas pendukung seperti hotel, apartement, mall, dan sebagainya sehingga menimbulkan perubahan tata guna lahan. Dalam kebijakan tersebut, Andalalin tidak hanya digunakan untuk mengatasi dampak dari suaru pembangunan dan syarat memperoleh IMB, tetapi menjadi salah satu basis data dalam kegiatan manajemen rekayasa lalu lintas [6].

Permasalahan lalu lintas di kota merupakan salah satu dampak akibat perubahan tataguna lahan, baik perubahan kategori maupun intensitasnya. Perubahan tersebut akan menarik dan membangkitkan lalu lintas baik kecil atupun besar yang kemudian membebani sistem jalan di kota. Pembebanan perjalanan yang melebihi kapasitas sistem jalan mengakibatkan kemacetan di sistem jalan kota. Dilatarbelakangi masalah tersebut, maka perlu diadakannya studi analisis dampak lalu lintas terhadap pembangunan yang mempengaruhi tata guna lahan, salah satunya terhadap pembangunan Apartemen Puncak Dharmahusada di Jl. Dr. Ir. Soekarno. Pembangunan Apartemen Puncak Dharmahusada dibangun di area dengan luas tanah $\pm 52.944 \mathrm{~m}^{2}$ dan bangunan $\pm 265.819 \mathrm{~m}^{2}$. Apartemen ini terdiri dari tiga tower dengan jumlah total terdiri dari 2.688 unit. Berdasarkan ketentuan Pedoman Teknis Analisis Dampak Lalu Lintas Akibat Pengembangan Kawasan di Perkotaan maka wajib dilakukan Andalalin [2].

Melihat Gambar 1 dapat dilihat bahwasanya pada studi kasus ini dilakukan evaluasi terhadap kinerja jaringan jalan di sekitar Apartemen Puncak Dharmahusada meliputi:

1. Simpang bersinyal Jl. Dr. Ir. Soekarno - Jl.Mulyorejo

2. Simpang bersinyal Jl. Persimpangan Jl. Dr. Ir. Soekarno - Jl. Kalijudan

3. Simpang bersinyal Jl. Persimpangan Jl. Dr. Ir. Soekarno - Jl. Kenjeran

4. Ruas Jl. Mulyorejo (barat)

5. Ruas Jl. Dr. Ir. Soekarno (segmen 1)

6. Ruas Jl. Mulyorejo (timur)

7. Ruas Jl. Kalijudan asri

8. Ruas Jl. Kalijudan

9. Ruas Jl. Kenjeran(barat)

10. Ruas Jl. Kenjeran(timur)

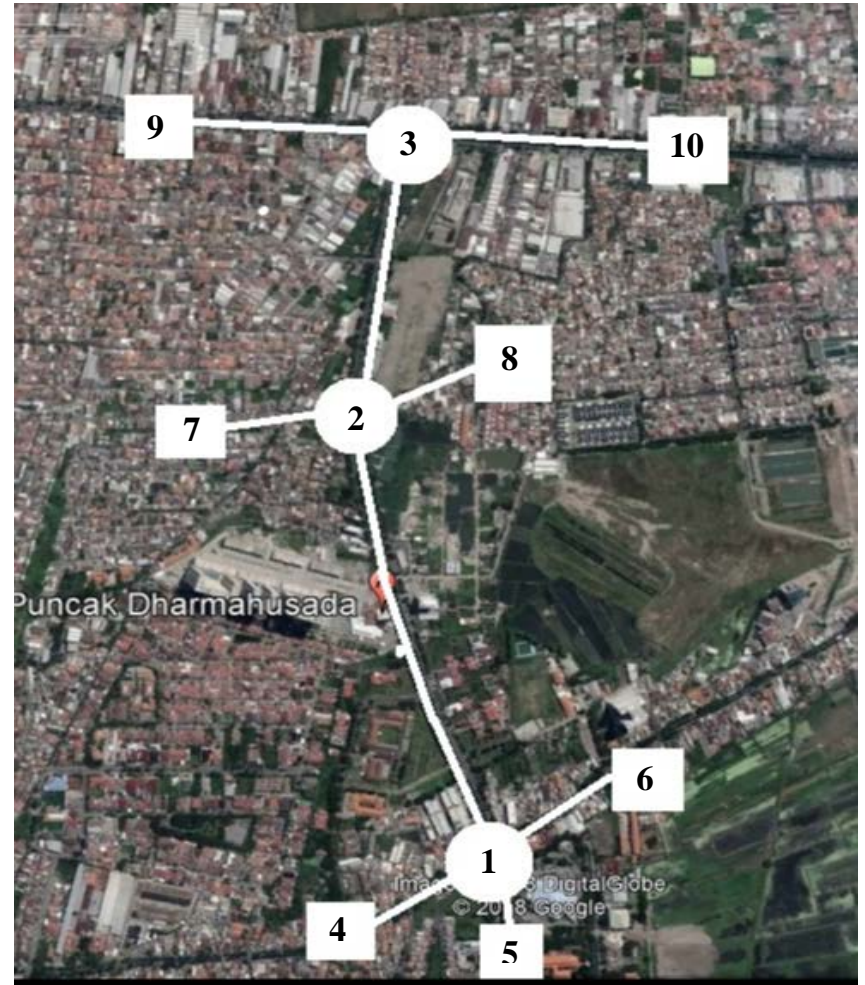

Gambar 1. Ruas jalan dan simpang yang terpengaruh

Tujuan dari analisis ini yaitu mengetahui kondisi lalu lintas disekitar kawasan pada kondisi eksisting (2018), 2 tahun masa pembangunan (2020), dan 5 tahun pasca beroperasi (2025) baik dengan pengembangan kawasan maupun tanpa pengembangan kawasan. Disamping itu juga mengetahui alternatif perbaikan penanganan dampak lalu lintas akibat pembangunan Apartemen Puncak Dharmahusada dan mengetahui kebutuhan parki pada gedung tersebut.

\section{Metode}

Tahap awal dalam kajian ini yaitu pengumpulan data yang mana dibagi menjadi 2 yaitu primer dan sekunder. Data primer yang dimaksud yaitu data geometrik jalan, volume lalu lintas pada simpang dan ruas terdekat, volume kendaraan keluar masuk bangunan pembanding untuk asumsi bangkitan tarikan, kondisi lingkungan. Sedangkan data sekunder yang dimaksud adalah peta tata guna lahan, luas bangunan gedung studi, luas bangunan gedung pembanding, data jumlah penduduk dan jumlah kendaraan bermotor.

Dari pengumpulan data diatas, selanjutnya berdasarkan MKJI 1997 dilakukan analisa pada simpang dan ruas jalan dengan beberapa kondisi, yaitu kondisi eksisting (2018), kondisi 2 tahun masa pembangunan (2020) baik tanpa maupun dengan pembangunan, kemudian kondisi 5 tahun 
pasca beroperasi (2025) baik tanpa maupun dengan pembangunan [3], [4], [5].

Setelah dilakukan analisa pada ruas dan simpang maka dapat diketahui dampak yang ditimbulkan oleh pembangunan Apartemen Puncak Dharmahusada tersebut. Bila kondisi simpang dan ruas memiliki $\mathrm{DS}<0,85$, maka tidak perlu dilakukan perbaikan, namun bila kondisi simpang dan ruas memiliki DS > 0,85 maka perlu dilakukan alternatif perbaikan [6],[7],[8],[9].

\section{Hasil dan Pembahasan}

\section{a. Prediksi bangkitan dan tarikan Apartemen Puncak Dharmahusada}

Dari Tabel 1-2 didapat asumsi kendaraan keluar masuk Apartemen Puncak Dharmahusada pada tiap jam puncak. Kendaraan tersebut diasumsikan akan membebani lalu lintas di sekitar kawasan yang nantinya volume kendaraan total yang masuk dan keluar tersebut akan tersebar di beberapa pergerakan dari simpang dan ruas jalan disekitar kawasan [10].

Tabel 1. Rekapitulasi prediksi jumlah kendaraan keluar masuk apartemen puncak dharmahusada pada hari kerja

\begin{tabular}{clcccc}
\hline \multirow{2}{*}{ Apartemen } & \multirow{2}{*}{$\begin{array}{c}\text { Periode } \\
\text { Waktu }\end{array}$} & \multicolumn{2}{c}{ Molume Kendaraan Per Jam } \\
& & SM & KR & SM & KR \\
\hline Apartemen & Pagi & 102 & 90 & 157 & 233 \\
Puncak & Siang & 152 & 117 & 129 & 124 \\
Dharmahusada & Sore & 111 & 193 & 114 & 175 \\
\hline
\end{tabular}

Tabel 2. Rekapitulasi prediksi jumlah kendaraan keluar masuk apartemen puncak dharmahusada pada hari libur

\begin{tabular}{clcccc}
\hline \multirow{2}{*}{ Apartemen } & \multirow{2}{*}{$\begin{array}{c}\text { Periode } \\
\text { Waktu }\end{array}$} & \multicolumn{2}{c}{ Molume Kendaraan Per Jam } \\
& SM & KR & SM & KR \\
\hline Apartemen & Pagi & 29 & 121 & 47 & 66 \\
Puncak & Siang & 57 & 112 & 45 & 115 \\
Dharmahusada & Sore & 40 & 267 & 139 & 131 \\
\hline
\end{tabular}

\section{b. Kondisi Eksisting Simpang Bersinyal dan Ruas}

Berdasarkan hasil rekapitulasi pada Tabel 3-4 dapat dilihat bahwa nilai kinerja simpang bersinyal Jl. Dr. Ir. Soekarno - Jl. Mulyorejo dengan tundaan paling tinggi 510,90 smp/jam dan nilai LOS terburuk adalah $\mathrm{F}$ pada hari kerja. Pada simpang bersinyal Jl. Dr. Ir. Soekarno - Jl. Kalijudan dengan tundaan paling tinggi 20,18 smp/jam dan nilai LOS terburuk adalah C pada hari kerja. Pada simpang bersinyal Jl. Dr. Ir. Soekarno - Jl. Kenjeran dengan tundaan paling tinggi 94,35 smp/jam dan nilai LOS terburuk adalah F pada hari kerja.
Tabel 3. Rekapitulasi hasil analisa simpang kondisi eksisting Tahun 2018

\begin{tabular}{|c|c|c|c|c|c|c|}
\hline \multirow[b]{2}{*}{ No } & \multirow[b]{2}{*}{ Simpang } & \multirow[b]{2}{*}{ Puncak } & \multicolumn{2}{|c|}{ Hari Kerja } & \multicolumn{2}{|c|}{ Hari Libur } \\
\hline & & & $\begin{array}{l}\text { Tundaan } \\
\text { Rata-rata } \\
\text { (det/smp) }\end{array}$ & LOS & $\begin{array}{l}\text { Tundaan } \\
\text { Rata-rata } \\
\text { (det/smp) }\end{array}$ & LOS \\
\hline \multirow[t]{3}{*}{1} & \multirow{3}{*}{$\begin{array}{c}\text { Jl. Dr. Ir. } \\
\text { Soekarno - } \\
\text { Jl. } \\
\text { Mulvoreio }\end{array}$} & Pagi & 510.90 & $\mathrm{~F}$ & 77.27 & $\mathrm{~F}$ \\
\hline & & Siang & 302.86 & $\mathrm{~F}$ & 192.63 & $\mathrm{~F}$ \\
\hline & & Sore & 417.82 & $\mathrm{~F}$ & 161.22 & $\mathrm{~F}$ \\
\hline \multirow[t]{3}{*}{2} & \multirow{3}{*}{$\begin{array}{c}\text { Jl. Dr. Ir. } \\
\text { Soekarno - } \\
\text { Jl. } \\
\text { Kalijudan }\end{array}$} & Pagi & 19.25 & $\mathrm{C}$ & 16.94 & $\mathrm{C}$ \\
\hline & & Siang & 18.39 & $\mathrm{C}$ & 17.77 & $\mathrm{C}$ \\
\hline & & Sore & 20.18 & $\mathrm{C}$ & 18.76 & $\mathrm{C}$ \\
\hline \multirow[t]{3}{*}{3} & \multirow{3}{*}{$\begin{array}{c}\text { Jl. Dr. Ir. } \\
\text { Soekarno - } \\
\text { Jl. Kenjeran }\end{array}$} & Pagi & 66.38 & $\mathrm{~F}$ & 20.08 & $\mathrm{C}$ \\
\hline & & Siang & 94.35 & $\mathrm{~F}$ & 26.18 & $\mathrm{D}$ \\
\hline & & Sore & 27.62 & $\mathrm{D}$ & 25.34 & $\mathrm{D}$ \\
\hline
\end{tabular}

Tabel 4. Rekapitulasi hasil analisa segmen kondisi eksisting tahun 2018

\begin{tabular}{|c|c|c|c|c|c|c|}
\hline \multirow[b]{2}{*}{ No } & \multirow[b]{2}{*}{ Nama Jalan } & \multirow[b]{2}{*}{ Periode } & \multicolumn{2}{|c|}{ Hari Kerja } & \multicolumn{2}{|c|}{ Hari Libur } \\
\hline & & & $\begin{array}{c}\text { Derajat } \\
\text { Kejenuh } \\
\text { an }\end{array}$ & LOS & $\begin{array}{c}\text { Derajat } \\
\text { Kejenuh } \\
\text { an }\end{array}$ & LOS \\
\hline \multirow[t]{3}{*}{1} & Jl. Dr. Ir. & Pagi & 0.425 & $\mathrm{~B}$ & 0.244 & $\mathrm{~B}$ \\
\hline & Soekarno & Siang & 0.293 & $\mathrm{~B}$ & 0.251 & B \\
\hline & (segmen 1) & Sore & 0.348 & B & 0.301 & B \\
\hline \multirow[t]{3}{*}{2} & Jl. Dr. Ir. & Pagi & 0.310 & B & 0.205 & B \\
\hline & Soekarno & Siang & 0.195 & A & 0.294 & B \\
\hline & (segmen 2) & Sore & 0.379 & B & 0.302 & B \\
\hline \multirow[t]{6}{*}{3} & $\mathrm{Jl}$. & Pagi & 0.424 & B & 0.233 & B \\
\hline & Mulyorejo & Siang & 0.349 & B & 0.294 & B \\
\hline & & Sore & 0.401 & B & 0.302 & B \\
\hline & & Pagi & 0.545 & $\mathrm{C}$ & 0.313 & B \\
\hline & & Siang & 0.368 & B & 0.403 & B \\
\hline & & Sore & 0.535 & $\mathrm{C}$ & 0.384 & B \\
\hline \multirow[t]{3}{*}{4} & Jl. Dr. Ir. & Pagi & 0.363 & B & 0.243 & B \\
\hline & Soekarno & Siang & 0.250 & B & 0.260 & B \\
\hline & (segmen 2) & Sore & 0.281 & B & 0.305 & B \\
\hline \multirow[t]{3}{*}{5} & Jl. Dr. Ir. & Pagi & 0.446 & B & 0.211 & B \\
\hline & Soekarno & Siang & 0.360 & B & 0.308 & B \\
\hline & (segmen 3) & Sore & 0.437 & B & 0.323 & B \\
\hline \multirow[t]{6}{*}{6} & $\mathrm{Jl}$. & Pagi & 0.080 & A & 0.079 & A \\
\hline & Kalijudan & Siang & 0.088 & $\mathrm{~A}$ & 0.081 & $\mathrm{~A}$ \\
\hline & & Sore & 0.082 & $\mathrm{~A}$ & 0.084 & A \\
\hline & & Pagi & 0.160 & A & 0.144 & A \\
\hline & & Siang & 0.168 & A & 0.157 & A \\
\hline & & Sore & 0.256 & B & 0.243 & B \\
\hline \multirow[t]{6}{*}{7} & Kenjeran & Pagi & 0.411 & B & 0.231 & B \\
\hline & & Siang & 0.351 & B & 0.295 & B \\
\hline & & Sore & 0.360 & B & 0.349 & B \\
\hline & & Pagi & 0.439 & B & 0.343 & B \\
\hline & & Siang & 0.392 & B & 0.415 & B \\
\hline & & Sore & 0.446 & $\mathrm{~B}$ & 0.428 & B \\
\hline
\end{tabular}

Berdasarkan rekapitulasi diatas dapat dilihat bahwa kondisi segmen pada kondisi eksisting masih bagus karena nilai LOS paling rendah adalah $\mathrm{B}$.

\section{c. Prediksi Lalu Lintas Sebelum Beroperasi Apartemen Pada Tahun 2020}

Berdasarkan hasil rekapitulasi Tabel 5. diatas dapat dilihat bahwa nilai kinerja simpang bersinyal Jl. Dr. Ir. Soekarno-Jl Mulyorejo pada tahun 2020 tanpa pembangungan 
menunjukkan menunjukkan tundaan paling tinggi 676.02 smp/jam dan nilai LOS terburuk adalah F pada hari kerja. Pada simpang bersinyal Jl. Dr. Ir. Soekarno - Jl. Kalijudan dengan tundaan paling tinggi 20,38 smp/jam dan nilai LOS terburuk adalah C pada hari kerja. Pada simpang bersinyal Jl. Dr. Ir. Soekarno - Jl. Kenjeran dengan tundaan paling tinggi 163,23 smp/jam dan nilai LOS terburuk adalah F pada hari kerja

Tabel 5. Rekapitulasi hasil simpang analisa tahun 2020 tanpa pengembangan

\begin{tabular}{|c|c|c|c|c|c|c|}
\hline \multirow[b]{2}{*}{ No } & \multirow[b]{2}{*}{ Simpang } & \multirow[b]{2}{*}{ Puncak } & \multicolumn{2}{|c|}{ Hari Kerja } & \multicolumn{2}{|c|}{ Hari Libur } \\
\hline & & & $\begin{array}{l}\text { Tundaan } \\
\text { Rata-rata } \\
\text { (det/smp) }\end{array}$ & LOS & $\begin{array}{l}\text { Tundaan } \\
\text { Rata-rata } \\
\text { (det/smp) }\end{array}$ & LOS \\
\hline \multirow[t]{3}{*}{1} & \multirow{3}{*}{$\begin{array}{c}\text { Jl. Dr. Ir. } \\
\text { Soekarno } \\
\text { - Jl. } \\
\text { Mulyorejo }\end{array}$} & Pagi & 676.02 & $\mathrm{~F}$ & 79.47 & $\mathrm{~F}$ \\
\hline & & Siang & 332.71 & $\mathrm{~F}$ & 219.35 & $\mathrm{~F}$ \\
\hline & & Sore & 592.54 & $\mathrm{~F}$ & 515.23 & $\mathrm{~F}$ \\
\hline \multirow[t]{3}{*}{2} & \multirow{3}{*}{$\begin{array}{c}\text { Jl. Dr. Ir. } \\
\text { Soekarno } \\
\text { - Jl. } \\
\text { Kalijudan }\end{array}$} & Pagi & 18.86 & $\mathrm{C}$ & 17.02 & $\mathrm{C}$ \\
\hline & & Siang & 17.97 & $\mathrm{C}$ & 18.14 & C \\
\hline & & Sore & 20.38 & $\mathrm{C}$ & 19.17 & $\mathrm{C}$ \\
\hline \multirow[t]{3}{*}{3} & \multirow{3}{*}{$\begin{array}{l}\text { Jl. Dr. Ir. } \\
\text { Soekarno } \\
\text { - Jl. } \\
\text { Kenjeran }\end{array}$} & Pagi & 126.41 & $\mathrm{~F}$ & 20.48 & $\mathrm{C}$ \\
\hline & & Siang & 163.23 & $\mathrm{~F}$ & 32.64 & $\mathrm{D}$ \\
\hline & & Sore & 33.37 & $\mathrm{D}$ & 29.25 & $\mathrm{D}$ \\
\hline
\end{tabular}

Berdasarkan rekapitulasi Tabel 6. diatas dapat dilihat bahwa kondisi segmen kondisi eksisting masih bagus karena nilai LOS paling rendah adalah C.

\section{d. Prediksi Lalu Lintas Sebelum Beroperasi Apartemen Pada Tahun 2025}

Berdasarkan hasil rekapitulasi Tabel 7 dapat dilihat bahwa nilai kinerja simpang bersinyal Jl. Dr. Ir. Soekarno Jl. Mulyorejo dengan tundaan paling tinggi 1319,22 smp/jam dan nilai LOS terburuk adalah F pada hari kerja. Pada simpang bersinyal Jl. Dr. Ir. Soekarno - Jl. Kalijudan dengan tundaan paling tinggi 29,29 smp/jam dan nilai LOS terburuk adalah D pada hari kerja. Pada simpang bersinyal Jl. Dr. Ir. Soekarno - Jl. Kenjeran dengan tundaan paling tinggi 390,59 smp/jam dan nilai LOS terburuk adalah F pada hari kerja.

Berdasarkan rekapitulasi Tabel 8 dapat dilihat bahwa kondisi segmen pada kondisi eksisting masih bagus karena nilai LOS paling rendah adalah $\mathrm{D}$.
Tabel 6. Rekapitulasi hasil analisa segmen jalan tahun 2020 tanpa pengembangan

\begin{tabular}{|c|c|c|c|c|c|c|}
\hline \multirow{3}{*}{ No } & \multirow{3}{*}{$\begin{array}{c}\text { Nama } \\
\text { Jalan }\end{array}$} & \multirow{3}{*}{ Periode } & \multicolumn{2}{|c|}{ Hari Kerja } & \multicolumn{2}{|c|}{ Hari Libur } \\
\hline & & & Derajat & & Derajat & \\
\hline & & & $\begin{array}{c}\text { Kejenuh } \\
\text { an }\end{array}$ & LOS & $\begin{array}{c}\text { Kejenuh } \\
\text { an }\end{array}$ & LOS \\
\hline \multirow[t]{3}{*}{1} & Jl. Dr. Ir. & Pagi & 0.467 & $\mathrm{C}$ & 0.268 & B \\
\hline & Soekarno & Siang & 0.322 & B & 0.276 & B \\
\hline & (segmen 1) & Sore & 0.382 & B & 0.330 & B \\
\hline \multirow[t]{3}{*}{2} & Jl. Dr. Ir. & Pagi & 0.341 & B & 0.225 & B \\
\hline & Soekarno & Siang & 0.214 & B & 0.323 & B \\
\hline & (segmen 2) & Sore & 0.430 & B & 0.337 & B \\
\hline \multirow[t]{6}{*}{3} & Jl. & Pagi & 0.466 & $\mathrm{C}$ & 0.256 & B \\
\hline & Mulyorejo & Siang & 0.384 & B & 0.323 & B \\
\hline & & Sore & 0.441 & B & 0.332 & B \\
\hline & & Pagi & 0.600 & $\mathrm{C}$ & 0.344 & B \\
\hline & & Siang & 0.404 & B & 0.443 & B \\
\hline & & Sore & 0.589 & $\mathrm{C}$ & 0.422 & B \\
\hline \multirow[t]{3}{*}{4} & Jl. Dr. Ir. & Pagi & 0.400 & B & 0.267 & B \\
\hline & Soekarno & Siang & 0.274 & B & 0.286 & B \\
\hline & (segmen 2) & Sore & 0.309 & B & 0.335 & B \\
\hline \multirow[t]{3}{*}{5} & Jl. Dr. Ir. & Pagi & 0.491 & $\mathrm{C}$ & 0.232 & B \\
\hline & Soekarno & Siang & 0.396 & B & 0.339 & B \\
\hline & (segmen 3) & Sore & 0.480 & $\mathrm{C}$ & 0.355 & B \\
\hline \multirow[t]{6}{*}{6} & Jl. & Pagi & 0.169 & A & 0.087 & A \\
\hline & Kalijudan & Siang & 0.182 & A & 0.089 & A \\
\hline & & Sore & 0.200 & A & 0.093 & A \\
\hline & & Pagi & 0.095 & A & 0.158 & A \\
\hline & & Siang & 0.100 & A & 0.173 & A \\
\hline & & Sore & 0.282 & B & 0.262 & B \\
\hline \multirow[t]{6}{*}{7} & Kenjeran & Pagi & 0.452 & $\mathrm{C}$ & 0.254 & B \\
\hline & & Siang & 0.385 & B & 0.324 & B \\
\hline & & Sore & 0.396 & B & 0.384 & B \\
\hline & & Pagi & 0.482 & $\mathrm{C}$ & 0.378 & B \\
\hline & & Siang & 0.430 & B & 0.456 & $\mathrm{C}$ \\
\hline & & Sore & 0.490 & $\mathrm{C}$ & 0.470 & $\mathrm{C}$ \\
\hline
\end{tabular}

Tabel 7. Rekapitulasi hasil simpang analisa tahun 2025 tanpa pengembangan

\begin{tabular}{|c|c|c|c|c|c|c|}
\hline \multirow[b]{2}{*}{ No } & \multirow[b]{2}{*}{ Simpang } & \multirow[b]{2}{*}{ Puncak } & \multicolumn{2}{|c|}{ Hari Kerja } & \multicolumn{2}{|c|}{ Hari Libur } \\
\hline & & & $\begin{array}{l}\text { Tundaan } \\
\text { Rata-rata } \\
\text { (det/smp) }\end{array}$ & LOS & $\begin{array}{l}\text { Tundaan } \\
\text { Rata-rata } \\
\text { (det/smp) }\end{array}$ & LOS \\
\hline \multirow[t]{3}{*}{1} & Jl. Dr. Ir. & Pagi & 1319.22 & $\mathrm{~F}$ & 183.66 & $\mathrm{~F}$ \\
\hline & Soekarno - & Siang & 646.39 & $\mathrm{~F}$ & 381.08 & $\mathrm{~F}$ \\
\hline & Mulyorejo & Sore & 1186.08 & $\mathrm{~F}$ & 657.91 & $\mathrm{~F}$ \\
\hline \multirow[t]{3}{*}{2} & Jl. Dr. Ir. & Pagi & 24.86 & $\mathrm{C}$ & 18.26 & $\mathrm{C}$ \\
\hline & Soekarno - & Siang & 21.26 & C & 19.90 & C \\
\hline & $\begin{array}{c}\text { Jl. } \\
\text { Kalijudan }\end{array}$ & Sore & 29.29 & $\mathrm{D}$ & 22.43 & $\mathrm{C}$ \\
\hline \multirow[t]{3}{*}{3} & Jl. Dr. Ir. & Pagi & 335.26 & $\mathrm{~F}$ & 35.30 & $\mathrm{D}$ \\
\hline & Soekarno - & Siang & 390.59 & $\mathrm{~F}$ & 148.85 & $\mathrm{~F}$ \\
\hline & Jl. Kenjeran & Sore & 141.49 & $\mathrm{~F}$ & 119.25 & $\mathrm{~F}$ \\
\hline
\end{tabular}


Tabel 8. Rekapitulasi hasil analisa segmen jalan tahun 2025 tanpa pengembangan

\begin{tabular}{|c|c|c|c|c|c|c|}
\hline \multirow[b]{2}{*}{ No } & \multirow[b]{2}{*}{ Nama Jalan } & \multirow[b]{2}{*}{ Periode } & \multicolumn{2}{|c|}{ Hari Kerja } & \multicolumn{2}{|c|}{ Hari Libur } \\
\hline & & & $\begin{array}{c}\text { Derajat } \\
\text { Kejenuh } \\
\text { an }\end{array}$ & LOS & $\begin{array}{c}\text { Derajat } \\
\text { Kejenuh } \\
\text { an }\end{array}$ & LOS \\
\hline \multirow[t]{3}{*}{1} & Jl. Dr. Ir. & Pagi & 0.593 & $\mathrm{C}$ & 0.340 & B \\
\hline & Soekarno & Siang & 0.408 & B & 0.349 & B \\
\hline & (segmen 1) & Sore & 0.484 & $\mathrm{C}$ & 0.418 & B \\
\hline \multirow[t]{3}{*}{2} & Jl. Dr. Ir. & Pagi & 0.433 & B & 0.285 & B \\
\hline & Soekarno & Siang & 0.271 & B & 0.408 & B \\
\hline & (segmen 2) & Sore & 0.530 & $\mathrm{C}$ & 0.421 & B \\
\hline \multirow[t]{6}{*}{3} & Jl. & Pagi & 0.592 & $\mathrm{C}$ & 0.325 & B \\
\hline & Mulyorejo & Siang & 0.486 & $\mathrm{C}$ & 0.409 & B \\
\hline & & Sore & 0.560 & $\mathrm{C}$ & 0.420 & B \\
\hline & & Pagi & 0.761 & $\mathrm{D}$ & 0.436 & B \\
\hline & & Siang & 0.512 & $\mathrm{C}$ & 0.560 & $\mathrm{C}$ \\
\hline & & Sore & 0.746 & $\mathrm{C}$ & 0.534 & $\mathrm{C}$ \\
\hline \multirow[t]{3}{*}{4} & Jl. Dr. Ir. & Pagi & 0.507 & $\mathrm{C}$ & 0.339 & B \\
\hline & Soekarno & Siang & 0.347 & B & 0.361 & B \\
\hline & (segmen 2) & Sore & 0.390 & B & 0.424 & B \\
\hline \multirow[t]{3}{*}{5} & Jl. Dr. Ir. & Pagi & 0.623 & $\mathrm{C}$ & 0.293 & B \\
\hline & Soekarno & Siang & 0.501 & $\mathrm{C}$ & 0.428 & B \\
\hline & (segmen 3) & Sore & 0.611 & $\mathrm{C}$ & 0.450 & $\mathrm{C}$ \\
\hline \multirow[t]{6}{*}{6} & Jl. & Pagi & 0.113 & A & 0.111 & A \\
\hline & Kalijudan & Siang & 0.123 & A & 0.113 & A \\
\hline & & Sore & 0.116 & A & 0.118 & A \\
\hline & & Pagi & 0.224 & B & 0.201 & B \\
\hline & & Siang & 0.235 & B & 0.219 & B \\
\hline & & Sore & 0.359 & B & 0.341 & B \\
\hline \multirow[t]{6}{*}{7} & Kenjeran & Pagi & 0.575 & $\mathrm{C}$ & 0.321 & B \\
\hline & & Siang & 0.487 & $\mathrm{C}$ & 0.410 & B \\
\hline & & Sore & 0.502 & $\mathrm{C}$ & 0.487 & $\mathrm{C}$ \\
\hline & & Pagi & 0.610 & $\mathrm{C}$ & 0.480 & $\mathrm{C}$ \\
\hline & & Siang & 0.546 & $\mathrm{C}$ & 0.577 & $\mathrm{C}$ \\
\hline & & Sore & 0.620 & $\mathrm{C}$ & 0.595 & $\mathrm{C}$ \\
\hline
\end{tabular}

\section{e. Prediksi Lalu Lintas dengan Beroperasi Apartemen Pada Tahun 2020}

Berdasarkan hasil rekapitulasi Tabel 9 dapat dilihat bahwa nilai kinerja simpang bersinyal Jl. Dr. Ir. Soekarno Jl. Mulyorejo dengan tundaan paling tinggi 799,83 smp/jam dan nilai LOS terburuk adalah F pada hari kerja. Pada simpang bersinyal Jl. Dr. Ir. Soekarno - Jl. Kalijudan dengan tundaan paling tinggi 21,94 smp/jam dan nilai LOS terburuk adalah C pada hari kerja. Pada simpang bersinyal Jl. Dr. Ir. Soekarno - Jl. Kenjeran dengan tundaan paling tinggi 263,56 smp/jam dan nilai LOS terburuk adalah F pada hari kerja.

Berdasarkan rekapitulasi Tabel 10. dibawah dapat dilihat bahwa kondisi segmen pada kondisi eksisting masih bagus karena nilai LOS paling rendah adalah $\mathrm{B}$.
Tabel 9. Rekapitulasi hasil analisa simpang tahun 2020 dengan pengembangan

\begin{tabular}{|c|c|c|c|c|c|c|}
\hline \multirow[b]{2}{*}{ No } & \multirow[b]{2}{*}{ Simpang } & \multirow[b]{2}{*}{ Puncak } & \multicolumn{2}{|c|}{ Hari Kerja } & \multicolumn{2}{|c|}{ Hari Libur } \\
\hline & & & $\begin{array}{l}\text { Tundaan } \\
\text { Rata-rata } \\
\text { (det/smp) }\end{array}$ & LOS & $\begin{array}{l}\text { Tundaan } \\
\text { Rata-rata } \\
\text { (det/smp) }\end{array}$ & LOS \\
\hline \multirow[t]{3}{*}{1} & Jl. Dr. Ir. & Pagi & 799.83 & $\mathrm{~F}$ & 81.08 & $\mathrm{~F}$ \\
\hline & Soekarno - & Siang & 350.55 & $\mathrm{~F}$ & 209.10 & $\mathrm{~F}$ \\
\hline & $\begin{array}{c}\text { Jl. } \\
\text { Mulyorejo }\end{array}$ & Sore & 689.94 & $\mathrm{~F}$ & 292.10 & $\mathrm{~F}$ \\
\hline \multirow[t]{3}{*}{2} & Jl. Dr. Ir. & Pagi & 21.08 & $\mathrm{C}$ & 17.08 & $\mathrm{C}$ \\
\hline & Soekarno - & Siang & 19.31 & $\mathrm{C}$ & 18.40 & $\mathrm{C}$ \\
\hline & $\begin{array}{c}\text { Jl. } \\
\text { Kalijudan }\end{array}$ & Sore & 21.94 & $\mathrm{C}$ & 19.78 & $\mathrm{C}$ \\
\hline \multirow[t]{3}{*}{3} & Jl. Dr. Ir. & Pagi & 207.95 & $\mathrm{~F}$ & 32.35 & $\mathrm{D}$ \\
\hline & Soekarno - & Siang & 263.56 & $\mathrm{~F}$ & 57.94 & $\mathrm{~F}$ \\
\hline & Jl. Kenjeran & Sore & 68.47 & $\mathrm{~F}$ & 53.22 & $\mathrm{E}$ \\
\hline
\end{tabular}

Tabel 10. Rekapitulasi hasil analisa segmen jalan tahun 2020 dengan pengembangan

\begin{tabular}{|c|c|c|c|c|c|c|}
\hline \multirow[b]{2}{*}{ No } & \multirow[b]{2}{*}{ Nama Jalan } & \multirow[b]{2}{*}{ Periode } & \multicolumn{2}{|c|}{ Hari Kerja } & \multicolumn{2}{|c|}{ Hari Libur } \\
\hline & & & $\begin{array}{c}\text { Derajat } \\
\text { Kejenuh } \\
\text { an }\end{array}$ & LOS & $\begin{array}{c}\text { Derajat } \\
\text { Kejenuh } \\
\text { an }\end{array}$ & LOS \\
\hline \multirow[t]{3}{*}{1} & Jl. Dr. Ir. & Pagi & 0.503 & $\mathrm{C}$ & 0.279 & $\mathrm{~B}$ \\
\hline & Soekarno & Siang & 0.345 & B & 0.290 & B \\
\hline & (segmen 1) & Sore & 0.408 & B & 0.356 & B \\
\hline \multirow[t]{3}{*}{2} & Jl. Dr. Ir. & Pagi & 0.362 & B & 0.241 & B \\
\hline & Soekarno & Siang & 0.245 & B & 0.341 & B \\
\hline & (segmen 2) & Sore & 0.449 & B & 0.363 & $\mathrm{~B}$ \\
\hline \multirow[t]{6}{*}{3} & $\mathrm{Jl}$. & Pagi & 0.471 & $\mathrm{C}$ & 0.259 & B \\
\hline & Mulyorejo & Siang & 0.397 & $\mathrm{~B}$ & 0.326 & B \\
\hline & & Sore & 0.447 & B & 0.335 & $\mathrm{~B}$ \\
\hline & & Pagi & 0.610 & $\mathrm{C}$ & 0.348 & B \\
\hline & & Siang & 0.415 & B & 0.450 & B \\
\hline & & Sore & 0.597 & $\mathrm{C}$ & 0.428 & B \\
\hline \multirow[t]{3}{*}{4} & Jl. Dr. Ir. & Pagi & 0.420 & B & 0.283 & B \\
\hline & Soekarno & Siang & 0.302 & B & 0.303 & B \\
\hline & (segmen 2) & Sore & 0.341 & B & 0.368 & B \\
\hline \multirow[t]{3}{*}{5} & Jl. Dr. Ir. & Pagi & 0.529 & $\mathrm{C}$ & 0.242 & $\mathrm{~B}$ \\
\hline & Soekarno & Siang & 0.422 & B & 0.354 & $\mathrm{~B}$ \\
\hline & (segmen 3) & Sore & 0.508 & C & 0.380 & B \\
\hline \multirow[t]{6}{*}{6} & & Pagi & 0.169 & A & 0.088 & A \\
\hline & & Siang & 0.184 & A & 0.090 & A \\
\hline & $\mathrm{Jl}$. & Sore & 0.201 & B & 0.094 & A \\
\hline & Kalijudan & Pagi & 0.101 & A & 0.160 & A \\
\hline & & Siang & 0.103 & A & 0.177 & A \\
\hline & & Sore & 0.289 & B & 0.277 & B \\
\hline \multirow[t]{6}{*}{7} & & Pagi & 0.479 & C & 0.324 & B \\
\hline & & Siang & 0.421 & B & 0.345 & $\mathrm{~B}$ \\
\hline & & Sore & 0.429 & B & 0.409 & B \\
\hline & Kenjeran & Pagi & 0.526 & C & 0.308 & B \\
\hline & & Siang & 0.462 & $\mathrm{C}$ & 0.419 & B \\
\hline & & Sore & 0.521 & C & 0.410 & $\mathrm{~B}$ \\
\hline
\end{tabular}

Berdasarkan Tabel 10 dapat dilihat bahwa kondisi segmen pada kondisi eksisting masi bagus karena nilai LOS paling rendah adalah $\mathrm{C}$. 


\section{f. Prediksi Lalu Lintas dengan Beroperasi Apartemen Pada Tahun 2025}

Berdasarkan hasil rekapitulasi pada Tabel 11. dapat dilihat bahwa nilai kinerja simpang bersinyal Jl. Dr. Ir. Soekarno - Jl. Mulyorejo dengan tundaan paling tinggi 3346,99 smp/jam dan nilai LOS terburuk adalah F pada hari kerja. Pada simpang bersinyal Jl. Dr. Ir. Soekarno - Jl. Kalijudan dengan tundaan paling tinggi 43,36 smp/jam dan nilai LOS terburuk adalah E pada hari kerja. Pada simpang bersinyal Jl. Dr. Ir. Soekarno - Jl. Kenjeran dengan tundaan paling tinggi 509,90 smp/jam dan nilai LOS terburuk adalah F pada hari kerja.

Berdasarkan rekapitulasi pada Tabel 12 dapat dilihat bahwa kondisi segmen pada kondisi eksisting masih bagus karena nilai LOS paling rendah adalah D.

Tabel 11. Rekapitulasi Hasil Analisa Simpang Tahun 2025 Dengan Pengembangan

\begin{tabular}{|c|c|c|c|c|c|c|}
\hline \multirow[b]{2}{*}{ No } & \multirow[b]{2}{*}{ Simpang } & \multirow[b]{2}{*}{ Puncak } & \multicolumn{2}{|c|}{ Hari Kerja } & \multicolumn{2}{|c|}{ Hari Libur } \\
\hline & & & $\begin{array}{l}\text { Tundaan } \\
\text { Rata-rata } \\
\text { (det/smp) }\end{array}$ & LOS & $\begin{array}{l}\text { Tundaan } \\
\text { Rata-rata } \\
\text { (det/smp) }\end{array}$ & LOS \\
\hline \multirow[t]{3}{*}{1} & Jl. Dr. Ir. & Pagi & 3346.99 & $\mathrm{~F}$ & 442.69 & $\mathrm{~F}$ \\
\hline & $\begin{array}{c}\text { Soekarno } \\
\text { - Jl }\end{array}$ & Siang & 728.94 & $\mathrm{~F}$ & 402.09 & $\mathrm{~F}$ \\
\hline & Mulyorejo & Sore & 1521.41 & F & 876.02 & $\mathrm{~F}$ \\
\hline \multirow[t]{3}{*}{2} & Jl. Dr. Ir. & Pagi & 33.18 & D & 18.45 & $\mathrm{C}$ \\
\hline & $\begin{array}{c}\text { Soekarno } \\
-\mathrm{Jl}\end{array}$ & Siang & 21.92 & $\mathrm{C}$ & 20.17 & $\mathrm{C}$ \\
\hline & Kalijudan & Sore & 43.36 & $\mathrm{E}$ & 23.08 & $\mathrm{C}$ \\
\hline \multirow[t]{3}{*}{3} & Jl. Dr. Ir. & Pagi & 462.75 & F & 35.75 & D \\
\hline & $\begin{array}{c}\text { Soekarno } \\
\text { - Jl }\end{array}$ & Siang & 509.90 & $\mathrm{~F}$ & 208.87 & $\mathrm{~F}$ \\
\hline & Kenjeran & Sore & 202.70 & $\mathrm{~F}$ & 188.78 & $\mathrm{~F}$ \\
\hline
\end{tabular}

\section{g. Alternatif Perbaikan}

Setelah dianalisa untuk tahun 2020 dan tahun 2025 tanpa maupun dengan pembangunan dari Apartemen Puncak Dharmahusada, didapat kondisi lalu lintas yang semakin jenuh dan hasil analisanya pun semakin memburuk. Perlu adanya alternatif perbaikan supaya hasil Analisa kinerja simpang dapat lebih baik dari kondisi sebelum dilakukannya alternatif perbaikan. Alternatif perbaikan yang dilakukan yaitu penggesaran U Turn pada pintu keluar masuk dekat Apartemen Puncak Dharmahusada, perubahan fase, dan perbaikan waktu hijau untuk simpang bersinyal Jl. Dr. Ir. Soekarno - Jl. Mulyorejo dan perubahan waktu hijau pada simpang bersinyal Jl. Dr. Ir. Soekarno - Jl.Kenjeran.
Tabel 12. Rekapitulasi Hasil Analisa Segmen Jalan Tahun 2025 dengan Pengembangan

\begin{tabular}{|c|c|c|c|c|c|c|}
\hline \multirow[b]{2}{*}{ No } & \multirow[b]{2}{*}{ Nama Jalan } & \multirow[b]{2}{*}{ Periode } & \multirow{2}{*}{$\begin{array}{c}\text { Derajat } \\
\text { Kejenuha } \\
\mathrm{n}\end{array}$} & \multicolumn{3}{|c|}{ Derajat } \\
\hline & & & & LOS & $\begin{array}{c}\text { Kejenu } \\
\text { han }\end{array}$ & LOS \\
\hline \multirow[t]{3}{*}{1} & Jl. Dr. Ir. & Pagi & 0.638 & C & 0.354 & B \\
\hline & \multirow{2}{*}{$\begin{array}{c}\text { Soekarno } \\
\text { (segmen 1) }\end{array}$} & Siang & 0.436 & B & 0.366 & B \\
\hline & & Sore & 0.517 & C & 0.450 & C \\
\hline \multirow[t]{3}{*}{2} & \multirow{3}{*}{$\begin{array}{l}\text { Jl. Dr. Ir. } \\
\text { Soekarno } \\
\text { (segmen 2) }\end{array}$} & Pagi & 0.460 & C & 0.306 & B \\
\hline & & Siang & 0.310 & B & 0.431 & B \\
\hline & & Sore & 0.571 & C & 0.459 & $\mathrm{C}$ \\
\hline \multirow[t]{6}{*}{3} & \multirow{6}{*}{$\begin{array}{c}\text { Jl. } \\
\text { Mulyorejo }\end{array}$} & Pagi & 0.598 & $\mathrm{C}$ & 0.329 & B \\
\hline & & Siang & 0.503 & C & 0.413 & B \\
\hline & & Sore & 0.566 & C & 0.424 & B \\
\hline & & Pagi & 0.774 & D & 0.441 & B \\
\hline & & Siang & 0.525 & $\mathrm{C}$ & 0.568 & $\mathrm{C}$ \\
\hline & & Sore & 0.757 & D & 0.541 & C \\
\hline \multirow[t]{3}{*}{4} & \multirow{3}{*}{$\begin{array}{l}\text { Jl. Dr. Ir. } \\
\text { Soekarno } \\
\text { (segmen 2) }\end{array}$} & Pagi & 0.533 & C & 0.359 & B \\
\hline & & Siang & 0.382 & B & 0.383 & B \\
\hline & & Sore & 0.431 & B & 0.465 & C \\
\hline \multirow[t]{3}{*}{5} & \multirow{3}{*}{$\begin{array}{l}\text { Jl. Dr. Ir. } \\
\text { Soekarno } \\
\text { (segmen 3) }\end{array}$} & Pagi & 0.672 & $\mathrm{C}$ & 0.307 & B \\
\hline & & Siang & 0.534 & C & 0.447 & B \\
\hline & & Sore & 0.645 & C & 0.481 & C \\
\hline \multirow[t]{6}{*}{6} & \multirow{6}{*}{$\begin{array}{c}\text { Jl. } \\
\text { Kalijudan }\end{array}$} & Pagi & 0.114 & A & 0.112 & A \\
\hline & & Siang & 0.125 & A & 0.115 & A \\
\hline & & Sore & 0.118 & A & 0.120 & A \\
\hline & & Pagi & 0.231 & B & 0.204 & B \\
\hline & & Siang & 0.239 & B & 0.224 & B \\
\hline & & Sore & 0.368 & B & 0.352 & B \\
\hline \multirow[t]{6}{*}{7} & \multirow{6}{*}{ Kenjeran } & Pagi & 0.608 & C & 0.274 & B \\
\hline & & Siang & 0.533 & C & 0.291 & B \\
\hline & & Sore & 0.545 & C & 0.345 & B \\
\hline & & Pagi & 0.666 & C & 0.260 & B \\
\hline & & Siang & 0.586 & C & 0.353 & B \\
\hline & & Sore & 0.659 & C & 0.345 & B \\
\hline
\end{tabular}

Berdasarkan Tabel 13 dapat lihat perbandingan kinerja kedua simpang bersinyal setelah dilakukan perbaikan. Pada simpang bersinyal Jl. Dr. Ir. Soekarno - Jl. Mulyorejo setelah dilakukan perbaikan fase dan waktu hijau terdapat perubahan yang signifikan pada tundaan. Alternatif perbaikan tersebut mengurangi waktu tundaan sehingga meningkatkan kinerja simpang tersebut. Nilai tingkat pelayanan jalan secara umum tidak meningkat secara signifikan, hanya terdapat peningkatan kinerja LOS dari nilai F menjad E pada tahun 2018 pada jam puncak siang. Secara keselurahan pada simpang bersinyal Jl. Dr. Ir. Soekarno - Jl. Mulyorejo hanya terjadi pengurangan tundaan. Pada simpang bersinyal Jl. Dr. Ir. Soekarno - Jl.Kenjeran setelah dilakukan perbaikan waktu hijau terdapat perubahan yang signifikan pada tundaan dan nilai LOS. Nilai tingkat pelayanan jalan secara umum meningkat secara signifikan, terdapat peningkatan kinerja LOS dari nilai F menjadi D pada tahun 2018 pada kondisi eksiting, 2020, dan 2025 dengan pengembangan.

Berdasarkan Tabel 15 dapat dilihat pada perbandingan kinerja kedua simpang bersinyal setelah diperbaiki. Pada 
simpang bersinyal Jl. Dr. Ir. Soekarno - Jl. Mulyorejo setalah dilakukan perbaikan fase dan waktu hijau terdapat perubahan yang signifikan pada tundaan dan nilai LOS. Secara umum peningkatan kinerja secara rata-rata LOS dari F menjadi D atau E pada tahun 2018 pada kondisi eksisting, 2020, dan 2025 dengan pengembangan. Pada simpang bersinyal Jl. Dr. Ir. Soekarno - Jl. Kenjeran setelah dilakukan perbaikan waktu hijau terdapat perubahan yang signifikan pada tundaan dan nilai LOS. Secara umum peningkatan kinerja rata-rata LOS dari nilai D menjadi C pada tahun 2018 pada kondisi eksiting, dari nilai E menjadi D pada tahun 2020 dengan pengembangan, dan dari nilai $\mathrm{F}$ menjadi $\mathrm{E}$ pada tahun 2025 dengan pengembangan. Rekapitulasi tingkat pelayanan pada simpang baik sebelum dilakukan perbaikan maupun setelah dilakukan perbaikan dapat dilihat pada Tabel 13-14.

Tabel 13. Hasil Rekapitulasi Tundaan Rata-rata Simpang dan Nilai LOS pada Tiap Simpang Bersinyal yang Telah dilakukan Perbaikan Pada Hari Kerja

\begin{tabular}{|c|c|c|c|c|c|c|c|c|c|c|c|c|c|}
\hline \multirow[b]{2}{*}{ Simpang } & \multirow[b]{2}{*}{ Periode } & \multicolumn{2}{|c|}{2018} & \multicolumn{2}{|c|}{ Perbaikan 2018} & \multicolumn{2}{|c|}{2020} & \multicolumn{2}{|c|}{ Perbaikan 2020} & \multicolumn{2}{|c|}{2025} & \multicolumn{2}{|c|}{ Perbaikan 2025} \\
\hline & & $\begin{array}{l}\text { Tundaan } \\
\text { Rata-rata } \\
\text { (det/smp) }\end{array}$ & LOS & $\begin{array}{l}\text { Tundaan } \\
\text { Rata-rata } \\
\text { (det/smp) }\end{array}$ & LOS & $\begin{array}{l}\text { Tundaan } \\
\text { Rata-rata } \\
\text { (det/smp) }\end{array}$ & LOS & $\begin{array}{l}\text { Tundaan } \\
\text { Rata-rata } \\
\text { (det/smp) }\end{array}$ & LOS & $\begin{array}{l}\text { Tundaan } \\
\text { Rata-rata } \\
\text { (det/smp) }\end{array}$ & LOS & $\begin{array}{l}\text { Tundaan } \\
\text { Rata-rata } \\
\text { (det/smp) }\end{array}$ & LOS \\
\hline \multirow{3}{*}{$\begin{array}{l}\text { Jl. Dr. Ir. } \\
\text { Soekarno - Jl. } \\
\text { Mulyorejo }\end{array}$} & Pagi & 510.90 & $\mathrm{~F}$ & 69.96 & $\mathrm{~F}$ & 799.83 & F & 138.2 & F & 3346.99 & F & 383.38 & F \\
\hline & Siang & 302.86 & $\mathrm{~F}$ & 48.67 & E & 350.55 & $\mathrm{~F}$ & 60.38 & F & 728.94 & $\mathrm{~F}$ & 212.25 & $\mathrm{~F}$ \\
\hline & Sore & 417.82 & F & 72.09 & F & 689.94 & $\mathrm{~F}$ & 145.95 & F & 1521.41 & $\mathrm{~F}$ & 522.93 & F \\
\hline \multirow{3}{*}{$\begin{array}{l}\text { Jl. Dr. Ir. } \\
\text { Soekarno - Jl. } \\
\text { Kenjeran }\end{array}$} & Pagi & 72.63 & $\mathrm{~F}$ & 40.08 & $\mathrm{D}$ & 207.95 & $\mathrm{~F}$ & 35.81 & $\mathrm{D}$ & 462.75 & $\mathrm{~F}$ & 58.74 & $\mathrm{E}$ \\
\hline & Siang & 104.49 & $\mathrm{~F}$ & 28.06 & $\mathrm{D}$ & 263.56 & $\mathrm{~F}$ & 30.72 & $\mathrm{D}$ & 509.90 & $\mathrm{~F}$ & 39.77 & $\mathrm{D}$ \\
\hline & Sore & 27.62 & D & 26.20 & D & 68.47 & F & 32.70 & D & 202.70 & $\mathrm{~F}$ & 40.62 & E \\
\hline
\end{tabular}

Tabel 14. Hasil Rekapitulasi Tundaan Rata-rata Simpang dan Nilai LOS pada Tiap Simpang Bersinyal yang Telah dilakukan Perbaikan Pada Hari Libur

\begin{tabular}{|c|c|c|c|c|c|c|c|c|c|c|c|c|c|}
\hline \multirow[b]{2}{*}{ Simpang } & \multirow[b]{2}{*}{ Periode } & \multicolumn{2}{|c|}{2018} & \multicolumn{2}{|c|}{ Perbaikan 2018} & \multicolumn{2}{|c|}{2020} & \multicolumn{2}{|c|}{ Perbaikan 2020} & \multicolumn{2}{|c|}{2025} & \multicolumn{2}{|c|}{ Perbaikan 2025} \\
\hline & & $\begin{array}{l}\text { Tundaan } \\
\text { Rata-rata } \\
\text { (det/smp) }\end{array}$ & LOS & $\begin{array}{l}\text { Tundaan } \\
\text { Rata-rata } \\
\text { (det/smp) }\end{array}$ & LOS & $\begin{array}{l}\text { Tundaan } \\
\text { Rata-rata } \\
\text { (det/smp) }\end{array}$ & LOS & $\begin{array}{l}\text { Tundaan } \\
\text { Rata-rata } \\
\text { (det/smp) }\end{array}$ & LOS & $\begin{array}{l}\text { Tundaan } \\
\text { Rata-rata } \\
\text { (det/smp) }\end{array}$ & LOS & $\begin{array}{l}\text { Tundaan } \\
\text { Rata-rata } \\
\text { (det/smp) }\end{array}$ & LOS \\
\hline \multirow{2}{*}{$\begin{array}{l}\text { Jl. Dr. Ir. } \\
\text { Soekarno - Jl. } \\
\text { Mulyorejo }\end{array}$} & Pagi & 77.27 & $\mathrm{~F}$ & 39.24 & $\mathrm{D}$ & 81.08 & $\mathrm{~F}$ & 34.82 & $\mathrm{D}$ & 442.69 & $\mathrm{~F}$ & 46.28 & $\mathrm{E}$ \\
\hline & Sore & 161.22 & $\mathrm{~F}$ & 47.22 & $\mathrm{E}$ & 292.10 & $\mathrm{~F}$ & 50.93 & $\mathrm{E}$ & 876.02 & $\mathrm{~F}$ & 109.97 & $\mathrm{~F}$ \\
\hline \multirow{2}{*}{$\begin{array}{l}\text { Jl. Dr. Ir. } \\
\text { Soekarno - Jl. } \\
\text { Kenjeran }\end{array}$} & Pagi & 20.08 & $\mathrm{C}$ & 20.09 & $\mathrm{C}$ & 32.35 & $\mathrm{D}$ & 32.12 & $\mathrm{D}$ & 35.75 & $\mathrm{D}$ & 36.92 & $\mathrm{D}$ \\
\hline & Sore & 25.34 & $\mathrm{D}$ & 25.05 & $\mathrm{C}$ & 53.22 & $\mathrm{E}$ & 34.45 & $\mathrm{D}$ & 188.78 & $\mathrm{~F}$ & 34.30 & $\mathrm{D}$ \\
\hline
\end{tabular}




\section{h. Analisa Parkir}

Kebutuhan parkir Apartemen Puncak Dharmahusada dapat ditentukan berdasarkan Peraturan Daerah No.7 Tahun 1992 yang analisanya sebagai berikut [5], [6]:

- Tiap 1 unit apartemen luasnya lebih besar dari $60 \mathrm{~m}^{2}$ maka wajib menyediakan 1 SRP.

- $\quad$ Tiap 3 unit apartemen luasnya 30-60 $\mathrm{m}^{2}$ maka wajib menyediakan 1 SRP.

- $\quad$ Tiap 5 unit apartemen luasnya kurang dari $60 \mathrm{~m}^{2}$ maka wajib menyediakan 1 SRP.

Tabel 15. Perhitungan kebutuhan satuan ruang parkir berdasarkan peraturan daerah Kota Surabaya No. 7 Tahun 1992

\begin{tabular}{|c|c|c|c|c|c|}
\hline $\begin{array}{l}\text { No. } \\
\text { (1) }\end{array}$ & $\begin{array}{l}\text { Tipe } \\
\text { Unit } \\
\text { (2) }\end{array}$ & $\begin{array}{l}\text { Luasan/ } \\
\text { Unit } \\
\text { (nett) } \\
\text { (3) }\end{array}$ & $\begin{array}{c}\text { Jumlah } \\
\text { Unit } \\
\text { (4) }\end{array}$ & $\begin{array}{l}\text { Luas } \\
\text { Total } \\
(\mathrm{m} 2) \\
(5)\end{array}$ & $\begin{array}{c}\text { Kebutuhan } \\
\text { Parkir } \\
\text { (6) }\end{array}$ \\
\hline & & & Tower A & & \\
\hline 1 & Tipe 1 & 18 & 192 & 3456 & 38 \\
\hline 2 & Tipe 2 & 48 & 704 & 33792 & 235 \\
\hline & & & Tower B & & \\
\hline 1 & Tipe 1 & 18 & 128 & 2304 & 26 \\
\hline 2 & Tipe 2 & 30 & 896 & 26880 & 299 \\
\hline & & & Tower C & & \\
\hline 1 & Tipe 1 & 36 & 64 & 2304 & 21 \\
\hline 2 & Tipe 2 & 48 & 512 & 24576 & 171 \\
\hline 3 & Tipe 3 & 84 & 160 & 13440 & 160 \\
\hline 4 & Tipe 4 & 79.5 & 32 & 2544 & 32 \\
\hline & \multicolumn{2}{|c|}{ Total } & 2688 & 109296 & 981 \\
\hline
\end{tabular}

Tabel 16. SRP yang tersedia

\begin{tabular}{clc}
\hline No & \multicolumn{1}{c}{ Fungsi } & Jumlah SRP \\
\hline 1 & Lantai dasar / P1 Keseluruhan & 771 \\
2 & Lantai P2 Keseluruhan & 417 \\
3 & Apartemen Lantai Ground P3/P4 & 312 \\
\hline \multicolumn{2}{c}{ Total } & 1500 \\
\hline
\end{tabular}

Dari data Tabel 14-15 dapat di lihat bahwa kebutuhan ruang parkir pada Apartemen Puncak Dharmahusada sebanyak 981 SRP roda empat sedangkan ketersediaan parkir yang ada sebanyak 1500 SRP roda empat. Dari data tersebut dapat disimpulkan bahwa kebutuhan ruang parkir yang tersedia mencukupi.

\section{Simpulan}

Dari hasil analisa pada bab sebelumnya didapatkan kondisi simpang bersinyal pada kondisi eksisting yang terbilang buruk dengan tingkat pelayanan (LOS) F pada seluruh periode puncak. Dapat dipastikan untuk 2 tahun dan 5 tahun kedepan tingkat pelayanan akan semakin memburuk karena adanya penambahan volume kendaraan akibat bangkitan, tarikan, maupun pertumbuhan kendaraan masyarakat yang naik setiap tahun. Adapun untuk ruang parkir pada Apartemen Puncak Dharmahusada telah mencukupi kebutuhan ruang parkir. Untuk itu perlu diberikan rekomendasi perbaikan simpang bersinyal Jl. Dr. Ir. Soekarno - Jl. Mulyorejo dengan melakukan perubahan fase dan waktu hijau, pada simpang bersinyal Jl. Dr. Ir. Soekarno - Jl. Kenjeran dengan melakukan perubahan waktu hijau dan yaitu penggesaran U Turn pada pintu keluar masuk dekat Apartemen Puncak Dharmahusada.

\section{Daftar Pustaka}

[1] R. Indonesia, UU Nomor 22 Tahun 2009 Tentang Lalu Lintas dan Angkutan Jalan. 2009, p. 209.

[2] Kemenhub, Peraturan Pemerintah No.32. 2011, pp. $1-58$.

[3] O. Z. Tamin, Perencanaan dan Pemodelan Transportasi. Bandung, 1997.

[4] IHCM, Indonesian Highway Capacity Manual, vol. 7802112, no. 264. 1997.

[5] Direktorat Bina Sistem Lalu Lintas dan Angkutan Kota, "Pedoman Perencanaan dan Pengoperasian Fasilitas Parkir.” 1998.

[6] Peraturan Daerah Kotamadya Tingkat II Surabaya No.7. 1992.

[7] Riky, dkk., "Analisis Dampak Lalu Lintas Pembangunan Surabaya Grammar School (SGS) Kota Surabaya," https://www.researchgate.net/publication/324687578 _Analisis_Dampak_Lalu_Lintas_Pembangunan_Sur abaya_Grammar_School_Sgs_Kota_Surabaya, April, 2018.

[8] Faturrahman A., dkk, "Analisa Dampak Lalu Lintas Akibat Pembangunan Kantor Telekomunikas Manyar Kertoadi 1 Surabaya,” https://www.researchgate.net/ publication/324687761_Analisis_Dampak_Lalu_Lin tas_Akibat_Pembangunan_Kantor_Telekomunikasi_ Manyar_Ketoadi_1_Surabaya, April, 2018.

[9] Fikri, dkk., “Analisis dampak lalu lintas akibat pembangunan apartement gunawangsa tidar surabaya,"

https://www.researchgate.net/publication/324687765 _Analisis_Dampak_Lalu_Lintas_Akibat_Pembangu nan_Apartement_Gunawangsa_Tidar_Surabaya, April, 2018.

[10] Kota Surabaya Dalam Angka 2017. Surabaya, 2017. 